Supporting Information for

\title{
Stable Pd-Cu Hydride Catalyst for Efficient Hydrogen Evolution
}

\author{
Yanyan Jia ${ }^{1}$, Tzu-Hsi Huang ${ }^{2}$, Shuan Lin $^{2}$, Lisheng Guo ${ }^{1}$, Yu-Min $\mathrm{Yu}^{2}$, \\ Jeng-Han Wang ${ }^{3}$, Kuan-Wen Wang ${ }^{2,4, *}$, Sheng Dai ${ }^{1, *}$
}

${ }^{1}$ Key Laboratory for Advanced Materials and Joint International Research Laboratory of Precision Chemistry and Molecular Engineering, Feringa Nobel Prize Scientist Joint Research Centre, Frontiers Science Center for Materiobiology and Dynamic Chemistry, Institute of Fine Chemicals, School of Chemistry and Molecular Engineering, East China University of Science \& Technology, Shanghai 200237, China

${ }^{2}$ Institute of Materials Science and Engineering, National Central University, Taoyuan 320, Taiwan

${ }^{3}$ Department of Chemistry, National Taiwan Normal University, Taipei 116, Taiwan

${ }^{4}$ Department of Materials Science and Engineering, National Taiwan University of Science and Technology, Taipei 10607, Taiwan

Corresponding Authors: Kuan-Wen Wang (kuanwen.wang@gmail.com) Sheng Dai (shengdai@ecust.edu.cn) 


\section{Materials Synthesis}

$\mathrm{Cu}\left(\mathrm{CH}_{3} \mathrm{COO}\right)_{2}$ and $\mathrm{Pd}\left(\mathrm{CH}_{3} \mathrm{COO}\right)_{2}$ were mixed in oleylamine, and heated to 353 $\mathrm{K}$ for 15 min under Ar. Then, the solution was heated to $450 \mathrm{~K}$ and refluxed for $2 \mathrm{~h}$. The carbon black was mixed with the above solution in hexane for $24 \mathrm{~h}$, washed several times with hexane/ethanol by centrifugation, and then filtrated. Finally, the products were annealed in air at $573 \mathrm{~K}$ for $5 \mathrm{~h}$ to obtain $\mathrm{PdCu} 0.2 \mathrm{H}_{0.43} / \mathrm{C}$ catalyst. Similarly, carbon supported $\mathrm{PdH}_{0.64}$ catalyst $\left(\mathrm{PdH}_{0.64} / \mathrm{C}\right)$ was prepared by the above procedures without the addition of copper acetate in the first step.

Moreover, additional Ar annealing step was carried out on $\mathrm{PdCu} 0.2 \mathrm{H}_{0.43} / \mathrm{C}\left(500{ }^{\circ} \mathrm{C}\right.$, 5 hours) to release the interstitial $\mathrm{H}$ atoms, then $\mathrm{PdCu}_{0.2} / \mathrm{C}$ catalyst was obtained. Besides, $\mathrm{Pd} / \mathrm{C}$ with Pd loading of $20 \mathrm{wt} \%$ (Alfa Aesar) was used for comparison.

Chemical compositions of the above catalysts were first revealed by inductively coupled plasma-optical emission spectrometer (ICP-OES, Agilent 725), and the result confirmed the 5:1 atomic ratio of $\mathrm{Pd}: \mathrm{Cu}$ in both $\mathrm{PdCu} 0.2 \mathrm{H}_{0.43} / \mathrm{C}$ and $\mathrm{PdCu} 0.2 / \mathrm{C}$ catalysts, as listed in Table S1.

\section{Materials Characterization}

$\mathrm{XRD}$ (Rigaku) using $\mathrm{Cu} \mathrm{K \alpha}(\lambda=0.154 \mathrm{~nm})$ radiation operated at $40 \mathrm{kV}$ and $40 \mathrm{~mA}$, and performed in a $2 \theta$ range from 10 to $90^{\circ}$ at a scan rate of $0.124^{\circ}$ per step. Aberrationcorrected TEM (AC-TEM) characterization was performed on a ThermoFisher Themis $\mathrm{Z}$ microscope equipped with two aberration correctors under $300 \mathrm{kV}$. High angle annular dark field (HAADF)-STEM images were recorded using a convergence semi angle of $11 \mathrm{mrad}$, and inner- and outer collection angles of 59 and $200 \mathrm{mrad}$, respectively. Energy dispersive X-ray spectroscopy (EDS) was carried out using 4 incolumn Super-X detectors.

The X-ray photoelectron spectroscopy (XPS, Thermo VG Scientific Sigma Probe) using an $\mathrm{A} 1 \mathrm{~K} \alpha$ radiation at a voltage of $20 \mathrm{kV}$ and a current of $30 \mathrm{~mA}$ was applied to detect the surface chemical states of catalysts. The base pressure in the analyzing chamber was maintained at $10^{-9}$ Torr, and all binding energies were calibrated with respect to the $\mathrm{C} 1 \mathrm{~s}$ line at $284.6 \mathrm{eV}$. The surface compositions of the samples were calculated from the peak areas of the corresponding lines, using a Shirley-type 
background for the XPS.

The X-ray absorption spectroscopy (XAS) was applied to unveil the atomic arrangements and electronic states of the experimental NCs. The XAS spectra of experimental samples were obtained in transmission mode at the beamlines BL-01C1 at the National Synchrotron Radiation Research Center (NSRRC), Taiwan. For data collection, all the catalysts were dispersed uniformly on the tape with an appropriate absorption thickness $(\mu \mathrm{x}=1.0$, where $\mu$ is the X-ray attenuation coefficient at the absorption edge and $\mathrm{x}$ is the thickness of the sample) to attain a proper edge jump. The ionization chamber filled with different mixing gases such as $\mathrm{Ar}, \mathrm{N}_{2}, \mathrm{He}$ or $\mathrm{Kr}$ was used to detect the intensities of the incident beam $\left(\mathrm{I}_{\mathrm{o}}\right)$, the fluorescence beam $\left(\mathrm{I}_{\mathrm{f}}\right)$ and the beam finally transmitted through a reference foil ( $\mathrm{I}_{\mathrm{r}}$ ) for X-ray energy calibration. Besides, the EXAFS analysis is carried out via subtracting the background of the pre/post-edge and subsequently normalizing with respect to the edge jump step from the XANES spectra $(\chi(E))$. The normalized $\chi(E)$ spectra were transformed from energy to $k$-space and further weighted by $k^{3}$ to discern the effect of backscattering interferences from different coordination shells. Subsequently, the extracted $k^{3}$ weighted spectra in $k$-space ranging from 3.0 to 10.8 for the Pd K-edge were Fourier transformed (FT) into $r$-space. Finally, the filtered EXAFS data were analyzed by a nonlinear least-squares curve fitting method in the $r$-space.

\section{Electrochemical Evaluation}

The HER measurements were carried out on a rotating electrode system (pine) with a CHI 6116 potentiostat. A three-electrode cell configuration was employed and glassy carbon, graphite rod, and silver chloride $(\mathrm{Ag} / \mathrm{AgCl})$ was used as a working, counter, and reference electrode, respectively. The $5 \mathrm{mg}$ of catalyst and $50 \mu \mathrm{l}$ of $5 \%$ Nafion 117 solution, as conducting binder, were introduced into $1 \mathrm{ml}$ of IPA and sonicated for $1 \mathrm{~h}$.

The electrocatalytic activities of catalysts toward the HER were investigated in $\mathrm{N}_{2}$ saturated $0.5 \mathrm{M} \mathrm{H}_{2} \mathrm{SO}_{4}$ by the linear sweep voltammetry (LSV) method which was conducted within the potential range from 0.20 to $-0.30 \mathrm{~V}$ (vs. RHE) at a sweeping rate of $2 \mathrm{mV} \mathrm{s}^{-1}$, and a rotational rate of $1600 \mathrm{rpm}$ in $\mathrm{N}_{2}$ saturated $0.5 \mathrm{M} \mathrm{H}_{2} \mathrm{SO}_{4}$ to remove the $\mathrm{H}_{2}$ generated at the electrode surface., and all the potentials are iR corrected. Prior 
to each test, the electrode was cycled several times between 0.00 and $1.20 \mathrm{~V}$ (vs. RHE) in $\mathrm{N}_{2}$ saturated $0.5 \mathrm{M} \mathrm{H}_{2} \mathrm{SO}_{4}$ to gain a relatively stable and clean surface. The Tafel slope shown in equation (1) can be used to describe the current-potential relationship at a significant overpotential $(\eta)$.

$$
\eta=a+b \cdot \log \left(j / j_{0}\right)
$$

where $j$ is the current density, $j_{0}$ is the exchange current density, $a$ is the Tafel intercept, and $b$ is the Tafel slope.

The electrochemical active surface area (ECSA) is defined as the exactly active area of the electrode material which is accessible to the electrolyte for charge transfer and calculated from the hydrogen desorption region in cyclic voltammetry (CV) curves for the catalysts. The scan region 17 was from 0.00 to $1.20 \mathrm{~V}$ (vs. RHE) at a sweep rate of $20 \mathrm{mV} \cdot \mathrm{s}^{-1}$ in $\mathrm{N}_{2}$ saturated $0.5 \mathrm{M} \mathrm{H}_{2} \mathrm{SO}_{4}$, and the ECSA of Pd was calculated from the hydrogen desorption region ECSAs was calculated from the CV curves according to the following formula (2) ${ }^{[1-3]}$ :

$$
\mathrm{ECSA}=\frac{Q_{H}}{[\mathrm{Pd}] \times 0.21}
$$

where [Pd] represents the platinum loading $\left(\mathrm{mg} \mathrm{cm}^{-2}\right)$ on the electrode, $0.21 \mathrm{mC} / \mathrm{cm}^{2}$ is the charge required to oxidize a monolayer of $\mathrm{H}_{2}$ on clean $\mathrm{Pd}$, and $Q_{\mathrm{H}}$ is the charge calculated from the area of hydrogen desorption peak in $\mathrm{CV}$ curve.

For the CO stripping voltammetry measurements, working electrodes coated with different catalysts were firstly immersed in a $\mathrm{CO}$ saturated $0.5 \mathrm{M} \mathrm{H}_{2} \mathrm{SO}_{4}$ solution for 5 min, and then the CO stripping voltammetry was recorded respectively between 0.05 to $1.2 \mathrm{~V}$ vs. RHE at a sweep rate of $50 \mathrm{mV} / \mathrm{s}$.

The accelerated degradation test (ADT) which was used to characterize the electrochemical stability and performance of the catalysts for HER was measured at the potential range from -0.10 to $0.2 \mathrm{~V}$ (vs. RHE) at a sweeping rate of $2 \mathrm{mV} \mathrm{s}^{-1}$ for 5000 cycles in $\mathrm{N}_{2}$ saturated $0.5 \mathrm{M} \mathrm{H}_{2} \mathrm{SO}_{4}$.

\section{DFT Calculation}

Density functional theory (DFT) calculations were applied through the Vienna ab 
initio simulation package (VASP) $)^{[4,5]}$. The Generalized Gradient Approximation $(\mathrm{GGA})^{[6]}$ with the Perdew-Burke-Ernzerhof (PBE) functional was used for all the calculations. $\mathrm{Pd}$ and $\mathrm{Pd}_{3} \mathrm{Cu}$ bulk structures were applied to build the catalyst surface of pure metal and PdCu alloy, which were both optimized with the Monkhorst-Pack kpoint of $4 \times 4 \times 4$. All the surface structures were cleaved to 4 layers with the periodicity of $\mathrm{p}(4 \times 4)$. For more specific modification, the alloy of $\mathrm{PdCu}_{0.2}$ was built based on the $\mathrm{Pd}_{3} \mathrm{Cu}$ bulk, where 1-2 $\mathrm{Cu}$ atoms were modified on $\mathrm{PdCu}_{0.2(111)}$ surface by $\mathrm{Pd}$ to realize the ratio of $\mathrm{Pd}: \mathrm{Cu}=5: 1$. The $\mathrm{PdH}_{0.64}(111)$ and $\mathrm{PdCu}_{0.2} \mathrm{H}_{0.43}(111)$ models were built by the insertion of $\mathrm{H}$ atoms in metal layers, according to the experimental ratios (See Fig. 1a). Note that, the lattice of $\mathrm{PdCu}_{0.2}(111), \mathrm{PdH}_{0.64}(111)$ and $\mathrm{PdCu}_{0.2} \mathrm{H}_{0.43}(111)$ were all optimized. A Monkhorst-Pack k-point $2 \times 2 \times 1$ was used for all the surface calculations with the cut-off energy of $400 \mathrm{eV}$. The structural optimization was conducted using the conjugate-gradient (CG) algorithm ${ }^{[7]}$, and the force convergence was set to be $0.05 \mathrm{eV} \cdot \AA^{-1}$. The standard free energies corrections ${ }^{[8,9]}$ was used to obtain the free energy at $298 \mathrm{~K}$. 
Table S1. Chemical compositions of Pd and Pd-based catalysts from ICP-OES.

\begin{tabular}{ccc}
\hline Samples & $\begin{array}{c}\text { Chemical composition } \\
(\mathbf{P d} / \mathbf{C u}) \mathbf{a t} \%\end{array}$ & $\begin{array}{c}\text { Metal loading } \\
(\mathbf{P d} / \mathbf{C u}) \mathbf{w t} \%\end{array}$ \\
\hline $\mathrm{Pd} / \mathrm{C}$ & $100 / 0$ & $20 / 0$ \\
$\mathrm{PdH}_{0.64} / \mathrm{C}$ & $100 / 0$ & $18 / 0$ \\
$\mathrm{PdCu}_{0.2} / \mathrm{C}$ & $84 / 16$ & $16 / 2$ \\
$\mathrm{PdCu}_{0.2} \mathrm{H}_{0.43} / \mathrm{C}$ & $84 / 16$ & $16 / 2$ \\
\hline
\end{tabular}

Table S2. XPS characterization of $\mathrm{Pd} / \mathrm{C}, \mathrm{PdH}_{0.64} / \mathrm{C}, \mathrm{PdCu}_{0.2} / \mathrm{C}$ and $\mathrm{PdCu}{ }_{0.2} \mathrm{H}_{0.43} / \mathrm{C}$.

\begin{tabular}{cccc}
\hline \multirow{2}{*}{ Sample } & \multicolumn{3}{c}{ Surface compositions (at \%) } \\
\cline { 2 - 4 } & $\mathbf{P d} / \mathbf{C u}$ & $\mathbf{P d} / \mathbf{P d}^{2+}$ & $\mathbf{C u} / \mathbf{C u}^{2+}$ \\
\hline $\mathrm{Pd} / \mathrm{C}$ & $100 / 0$ & $43 / 57$ & - \\
$\mathrm{PdCu}{ }_{0.2} / \mathrm{C}$ & $83 / 17$ & $75 / 25$ & $52 / 48$ \\
$\mathrm{PdH}_{0.64} / \mathrm{C}$ & $100 / 0$ & $85 / 15$ & - \\
$\mathrm{PdCu}_{0.2 \mathrm{H}_{0.43} / \mathrm{C}}$ & $82 / 18$ & $90 / 10$ & $74 / 26$ \\
\hline
\end{tabular}


Table S3. XAS model analysis of the $\mathrm{Pd} / \mathrm{C}, \mathrm{PdH}_{0.64} / \mathrm{C}, \mathrm{PdCu}_{0.2} / \mathrm{C}$, and $\mathrm{PdCu}_{0.2} \mathrm{H}_{0.43} / \mathrm{C}$ at Pd Kedge.

\begin{tabular}{|c|c|c|c|c|c|c|c|}
\hline \multirow{2}{*}{ Sample } & \multicolumn{4}{|c|}{ Neighboring atom $\mathrm{CN}^{*}$} & \multicolumn{3}{|c|}{$\mathbf{R}(\AA) *$} \\
\hline & Pd & $\mathbf{C u}$ & $\mathbf{O}$ & $\mathbf{C N}_{\text {total }}$ & Pd & $\mathrm{Cu}$ & $\mathbf{O}$ \\
\hline $\mathrm{Pd} / \mathrm{C}$ & 1.71 & 0 & 3.22 & 4.93 & 2.741 & 0 & 2.004 \\
\hline $\mathrm{PdH}_{0.64} / \mathrm{C}$ & 7.83 & 0 & 0.32 & 8.15 & 2.745 & 0 & 2.034 \\
\hline $\mathrm{PdCu}_{0.2} / \mathrm{C}$ & 4.46 & 0.90 & 0.89 & 6.25 & 2.737 & 2.246 & 2.040 \\
\hline $\mathrm{PdCu}_{0.2} \mathrm{H}_{0.43} / \mathrm{C}$ & 4.59 & 1.20 & 0.42 & 6.21 & 2.739 & 2.248 & 2.045 \\
\hline
\end{tabular}

*CN: coordination number; $\mathbf{C N}_{\text {total }}$ : total $\mathrm{CN}$ around $\mathrm{Pt}$ atom; $\mathrm{R}$ : atomic distance; $\sigma^{2}$ is $0.004, \Delta \mathrm{E}_{0}$ is $7.0-8.5, \mathrm{R}$ factor is 0.003 to 0.006 for all fitting models.

Table S4. The ECSAco of $\mathrm{Pd} / \mathrm{C}, \mathrm{PdH}_{0.64} / \mathrm{C}, \mathrm{PdCu}_{0.2} / \mathrm{C}$, and $\mathrm{PdCu} 0.2 \mathrm{H}_{0.43} / \mathrm{C}$.

\begin{tabular}{cc}
\hline Samples & ECSACo $\left(\mathrm{m}^{2} / \mathrm{g}_{\mathrm{Pd}}\right)$ \\
\hline $\mathrm{Pd} / \mathrm{C}$ & 104 \\
$\mathrm{PdCu}_{0.2} / \mathrm{C}$ & 129 \\
$\mathrm{PdH}_{0.64} / \mathrm{C}$ & 133 \\
$\mathrm{PdCu}_{0.2} \mathrm{H}_{0.43} / \mathrm{C}$ & 173 \\
\hline
\end{tabular}


Table S5. Electrocatalytic performances $\mathrm{Pt} / \mathrm{C}$ before and after the stability test.

\begin{tabular}{ccccc}
\hline \multirow{2}{*}{ Sample } & Condition & $\begin{array}{c}\boldsymbol{\eta}^{*} @ \mathbf{1 0} \mathbf{~ m A} \\
\mathbf{c m}^{-\mathbf{2}} \mathbf{( m \mathbf { V } )}\end{array}$ & $\begin{array}{c}\text { Tafel slope } \\
\left(\mathbf{m V} \mathbf{~} \mathbf{d e c}^{-\mathbf{1}}\right)\end{array}$ & $\begin{array}{c}\text { ECSA } \\
\left(\mathbf{m}^{\mathbf{2}} \mathbf{g}^{\mathbf{- 1}}\right)\end{array}$ \\
\hline \multirow{2}{*}{$\mathrm{Pt} / \mathrm{C}$} & As-prepared & 35 & 30 & 132 \\
\cline { 2 - 5 } & After ADT & 46 & 39 & 87 \\
\hline
\end{tabular}

Table S6. Current densities $(j)$ and turnover frequencies (TOFs) at $0.1 \mathrm{~V}$ of $\mathrm{Pd} / \mathrm{C}$, $\mathrm{PdH}_{0.64} / \mathrm{C}, \mathrm{PdCu}_{0.2} / \mathrm{C}$, and $\mathrm{PdCu}_{0.2} \mathrm{H}_{0.43} / \mathrm{C}$ catalysts.

\begin{tabular}{|c|c|c|}
\hline Samples & $\left.j @ 0.1 \mathrm{~V}(\mathrm{~mA} \mathrm{~cm})^{-2}\right)$ & TOF $@ 0.1 V\left(\mathrm{~s}^{-1}\right)$ \\
\hline $\mathrm{Pd} / \mathrm{C}$ & 19.0 & 0.13 \\
\hline $\mathrm{PdCu}_{0.2} / \mathrm{C}$ & 82.6 & 0.54 \\
\hline $\mathrm{PdH}_{0.64} / \mathrm{C}$ & 192.4 & 1.30 \\
\hline $\mathrm{PdCu}_{0.2} \mathrm{H}_{0.43} / \mathrm{C}$ & 207.0 & 1.34 \\
\hline
\end{tabular}


Table S7. Comparison of HER performance among all $\mathrm{PdCu}$ catalysts in this study and from literatures.

\begin{tabular}{|c|c|c|c|c|c|c|}
\hline Samples & $\begin{array}{c}\mathrm{H}_{2} \mathrm{SO}_{4} \\
\text { concentration, } \\
\text { Scan rate } \\
\end{array}$ & $\begin{array}{c}\eta^{10} \\
(\mathrm{mV})\end{array}$ & $\begin{array}{l}\text { Tafel slope } \\
\left(\mathrm{mV} \mathrm{dec}{ }^{-1}\right)\end{array}$ & $\begin{array}{c}\mathrm{MA} \\
\left(\mathrm{A}_{\mathrm{Pd}}^{-1}\right)\end{array}$ & $\begin{array}{l}\text { ECSA } \\
\left(\mathrm{m}^{2} \mathrm{~g}^{-1}\right)\end{array}$ & Ref. \\
\hline $\mathbf{P d H}_{0.64}$ & $\begin{array}{c}0.5 \mathrm{M}, \\
2 \mathrm{mVs}^{-1}\end{array}$ & 30 & 27 & $\begin{array}{c}335 \\
@-0.05 \mathrm{~V} \\
\end{array}$ & 126 & This work \\
\hline $\mathrm{Pd}$ & $\begin{array}{c}0.5 \mathrm{M} \\
5 \mathrm{mVs}^{-1}\end{array}$ & 115.5 & 121 & $\begin{array}{c}46 \\
@-0.05 \mathrm{~V}\end{array}$ & - & 10 \\
\hline Icosahedral Pd & $\begin{array}{c}0.5 \mathrm{M} \\
10 \mathrm{mVs}^{-1}\end{array}$ & 32 & 32.5 & - & 21 & 1 \\
\hline $\mathrm{PdCu}_{0.2} \mathrm{H}_{0.43}$ & $\begin{array}{c}0.5 \mathrm{M} \\
2 \mathrm{mVs}^{-1}\end{array}$ & 28 & 23 & $\begin{array}{c}435 \\
@-0.05 \mathrm{~V}\end{array}$ & 173 & This work \\
\hline $\mathrm{Pd}_{71} \mathrm{Cu}_{29}$ & $\begin{array}{c}0.1 \mathrm{M} \\
5 \mathrm{mVs}^{-1}\end{array}$ & 75 & 48 & $\begin{array}{c}1251 \\
@-0.10 \mathrm{~V}\end{array}$ & 78 & 11 \\
\hline $\begin{array}{c}\mathrm{PdCu} \\
\text { Nanorod }\end{array}$ & $\begin{array}{l}0.5 \mathrm{M} \\
5 \mathrm{mVs}^{-1}\end{array}$ & 111.5 & 98 & $\begin{array}{c}59 \\
@-0.05 \mathrm{~V}\end{array}$ & - & 10 \\
\hline $\mathrm{PdCu}$ alloy & $\begin{array}{c}0.5 \mathrm{M} \\
5 \mathrm{mVs}^{-1}\end{array}$ & 80 & 51 & - & 13.6 & 2 \\
\hline $\mathrm{PdCu}_{3}$ & \multirow{2}{*}{$\begin{array}{c}0.5 \mathrm{M} \\
1 \mathrm{mVs}^{-1}\end{array}$} & 209 & 104 & - & - & \multirow[b]{2}{*}{12} \\
\hline $\begin{array}{c}\text { Dealloyed } \\
\mathrm{PdCu} \\
\end{array}$ & & 50 & 34 & - & - & \\
\hline $\begin{array}{l}\mathrm{PdCu} @ \mathrm{Pd} \\
\text { Nanocube }\end{array}$ & $0.5 \mathrm{M}$ & 68 & 35 & - & - & 13 \\
\hline $\mathrm{PdCu}$ & $\begin{array}{c}0.1 \mathrm{M} \mathrm{HClO}_{4} \\
5 \mathrm{mVs}^{-1} \\
\end{array}$ & 45 & - & $\begin{array}{c}870 \\
@-0.02 \mathrm{~V} \\
\end{array}$ & & 14 \\
\hline
\end{tabular}




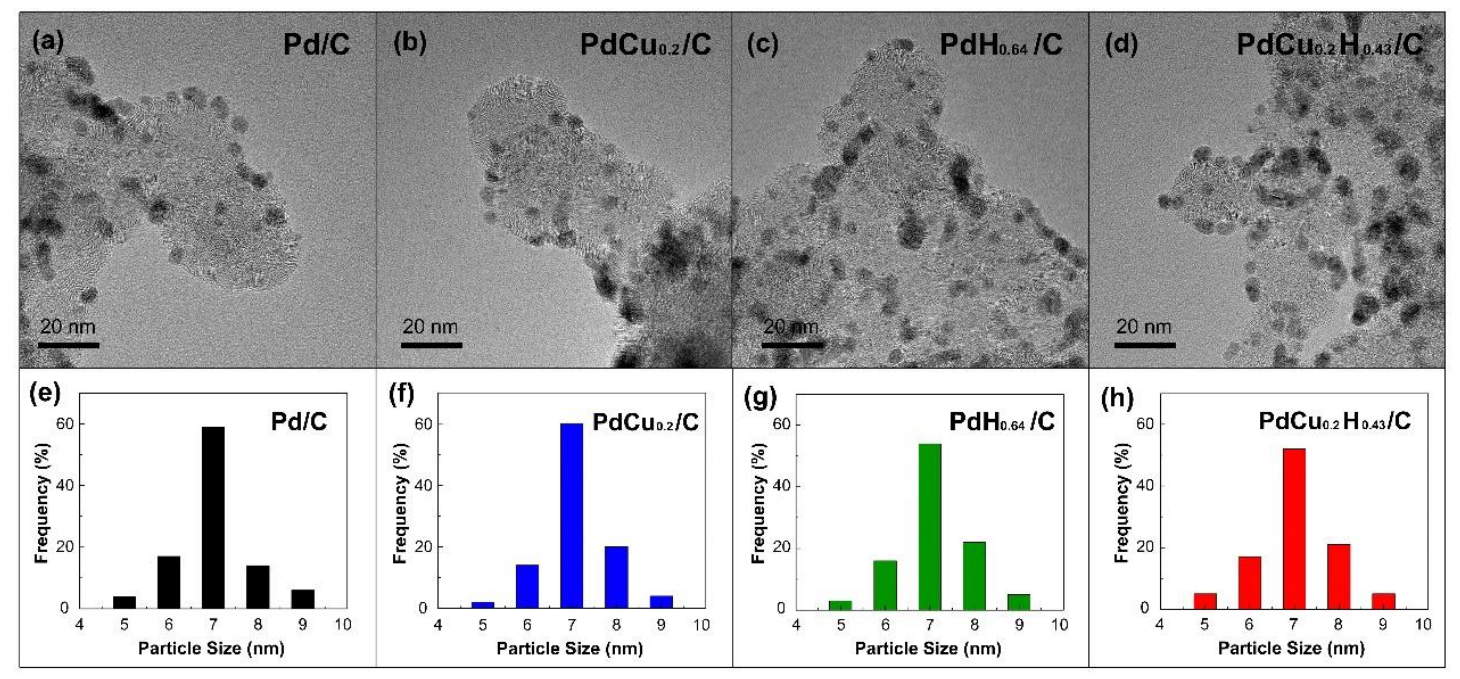

Figure S1. TEM characterization and statistical result of $\mathrm{Pd} / \mathrm{C}, \mathrm{PdCu} 0.2 / \mathrm{C}, \mathrm{PdH}_{0.64} / \mathrm{C}$, and $\mathrm{PdCu} 0.2 \mathrm{H}_{0.43} / \mathrm{C}$ catalysts.
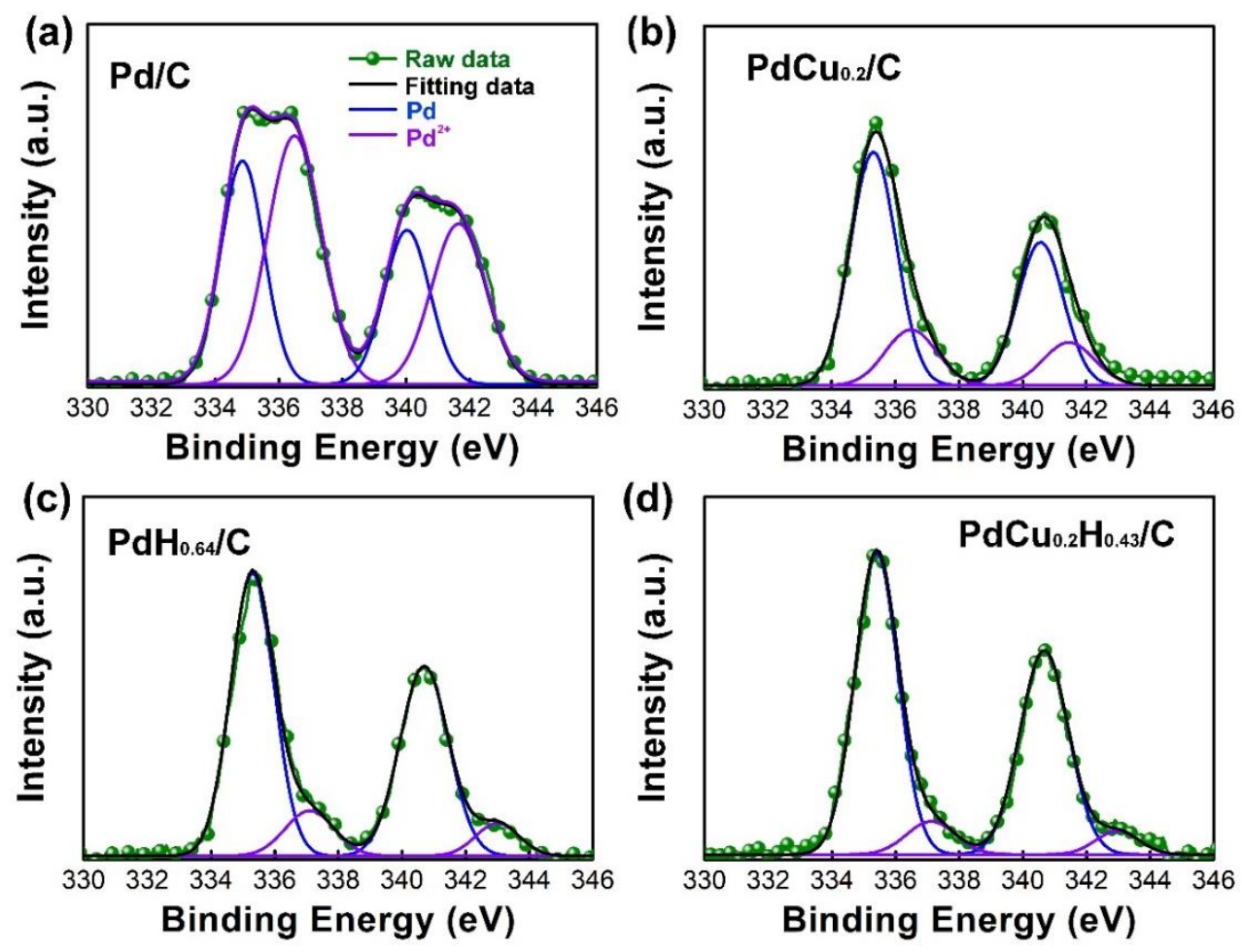

Figure S2. XPS spectra of Pd 3d for (a) Pd/C, (b) $\mathrm{PdCu}_{0.2} / \mathrm{C}$, (c) $\mathrm{PdH} 0.64 / \mathrm{C}$, and (d) $\mathrm{PdCu}_{0.2} \mathrm{H}_{0.43} / \mathrm{C}$. 


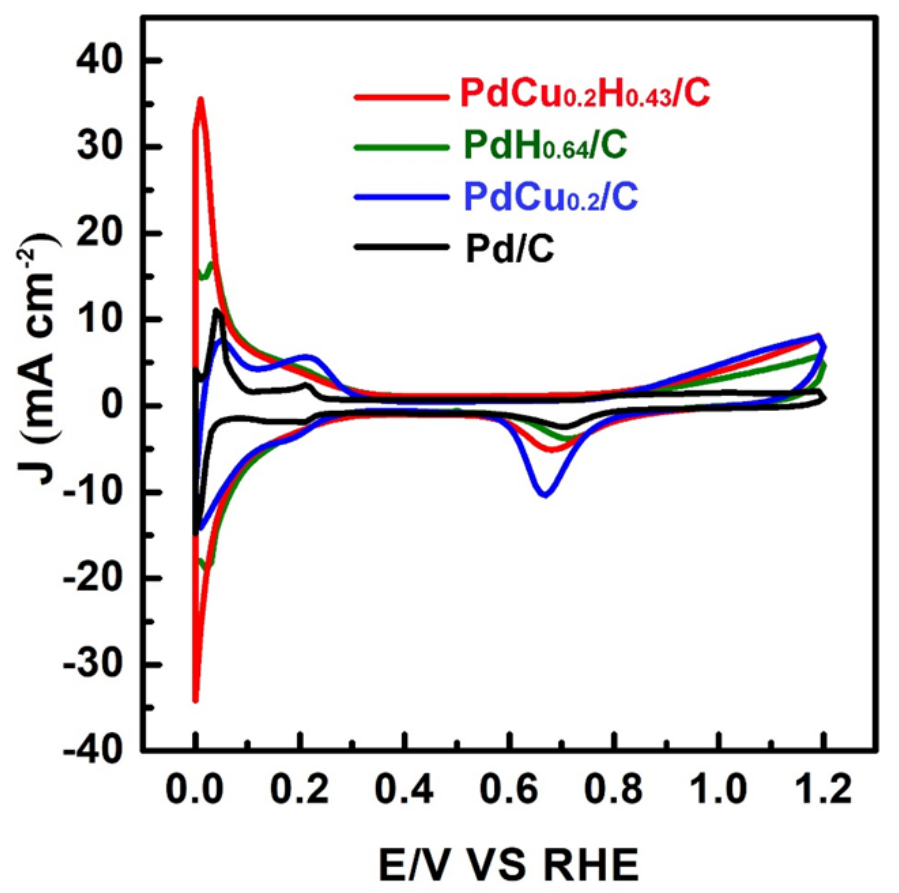

Figure S3. The $\mathrm{CV}$ curves of $\mathrm{PdCu}_{0.2} \mathrm{H}_{0.43} / \mathrm{C}, \mathrm{PdCu}_{0.2} / \mathrm{C}, \mathrm{PdH}_{0.64} / \mathrm{C}$, and $\mathrm{Pd} / \mathrm{C}$ in $0.5 \mathrm{M}$ $\mathrm{H}_{2} \mathrm{SO}_{4}$.

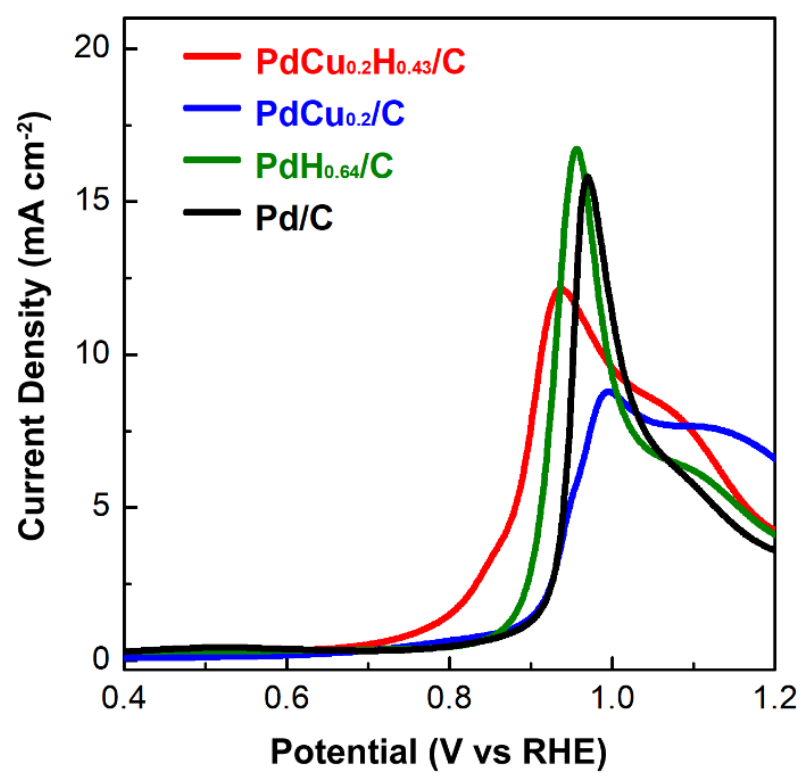

Figure S4. The CO-stripping results of $\mathrm{Pd} / \mathrm{C}, \mathrm{PdH}_{0.64} / \mathrm{C}, \mathrm{PdCu}_{0.2} / \mathrm{C}$, and $\mathrm{PdCu} \mathrm{Cu}_{0.2} \mathrm{H}_{0.43} / \mathrm{C}$ catalysts performed in $0.5 \mathrm{M} \mathrm{H}_{2} \mathrm{SO}_{4}$ at a scan rate of $50 \mathrm{mV} / \mathrm{s}$. 

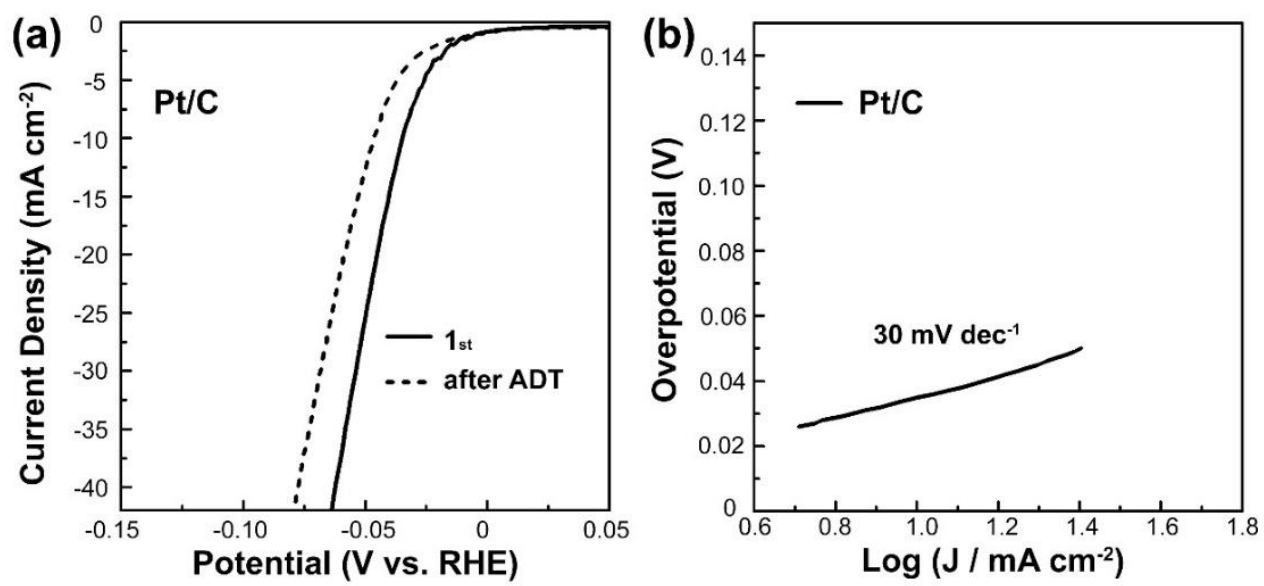

Figure S5. Electrochemical evaluation of $\mathrm{Pt} / \mathrm{C}$ HER catalysts. (a) linear sweep voltammetry before and after 5000 cycles in $0.5 \mathrm{M} \mathrm{H}_{2} \mathrm{sO}_{4}$, and (b) the Tafel plot.

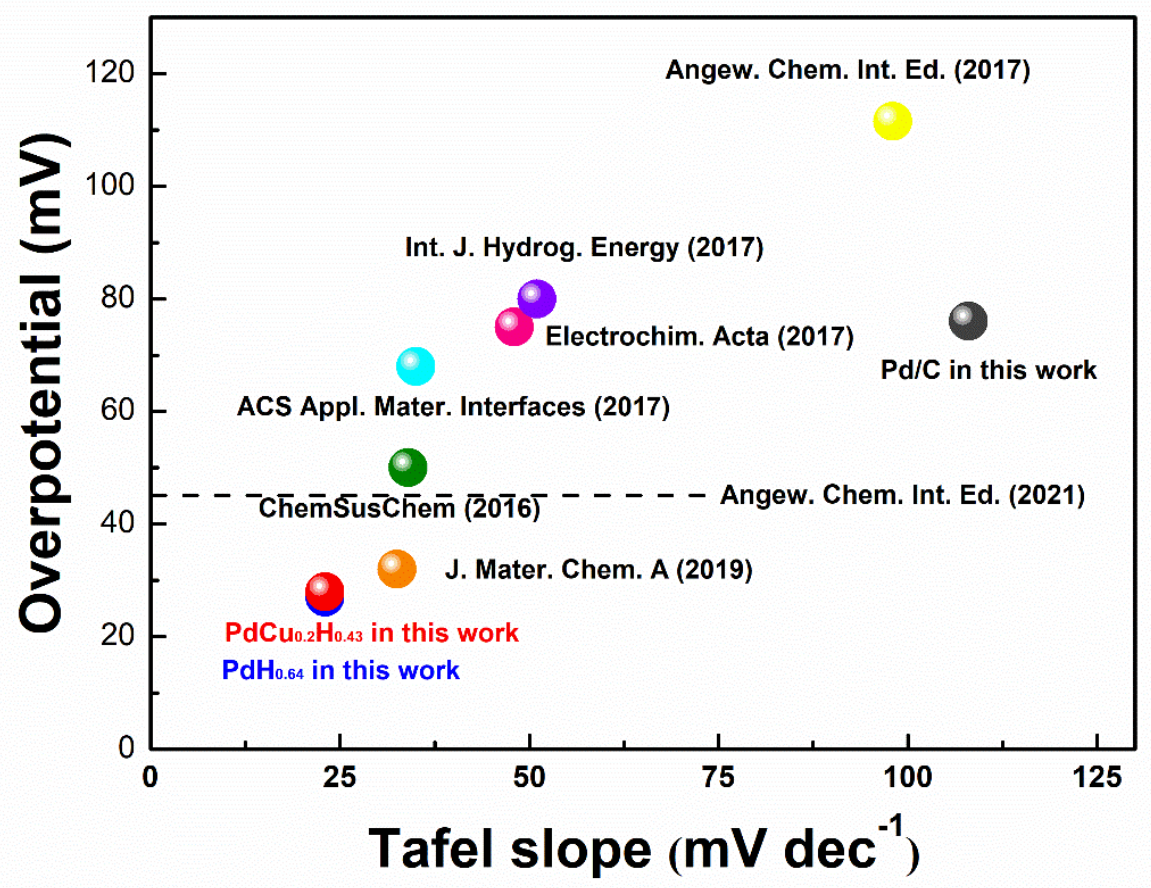

Figure S6. Overpotentials and Tafel slopes of $\mathrm{Pd}$ and $\mathrm{PdCu}$ catalysts in this study and from literatures. 

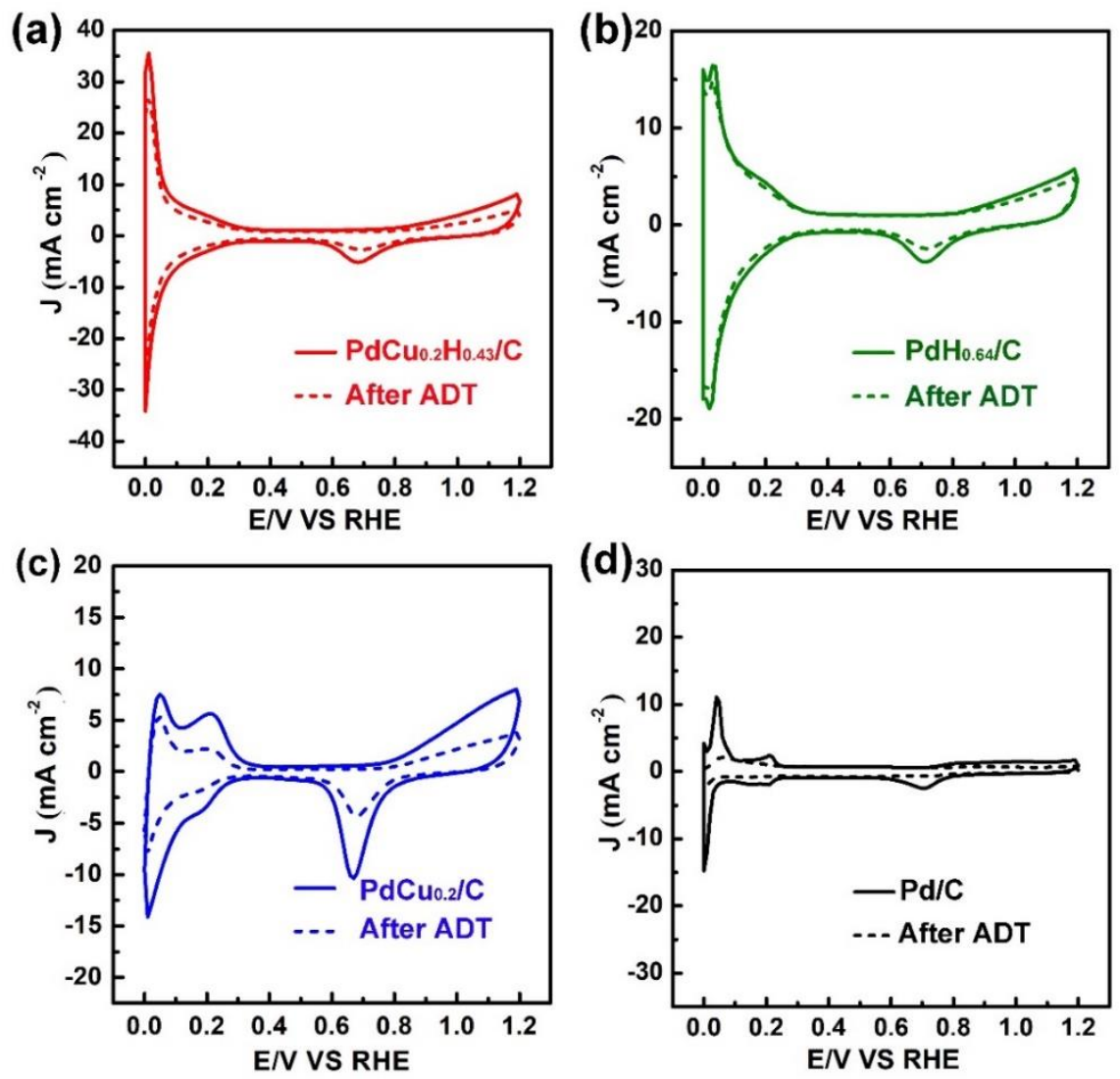

Figure S7. CV curves for (a) $\mathrm{PdCu}_{0.2} \mathrm{H}_{0.43} / \mathrm{C}$, (b) $\mathrm{PdH} \mathrm{H}_{0.64} / \mathrm{C}$, (c) $\mathrm{PdCu} 0.2 / \mathrm{C}$, and (d) $\mathrm{Pd} / \mathrm{C}$ before and after 5000 cycles in $0.5 \mathrm{M} \mathrm{H}_{2} \mathrm{SO}_{4}$.

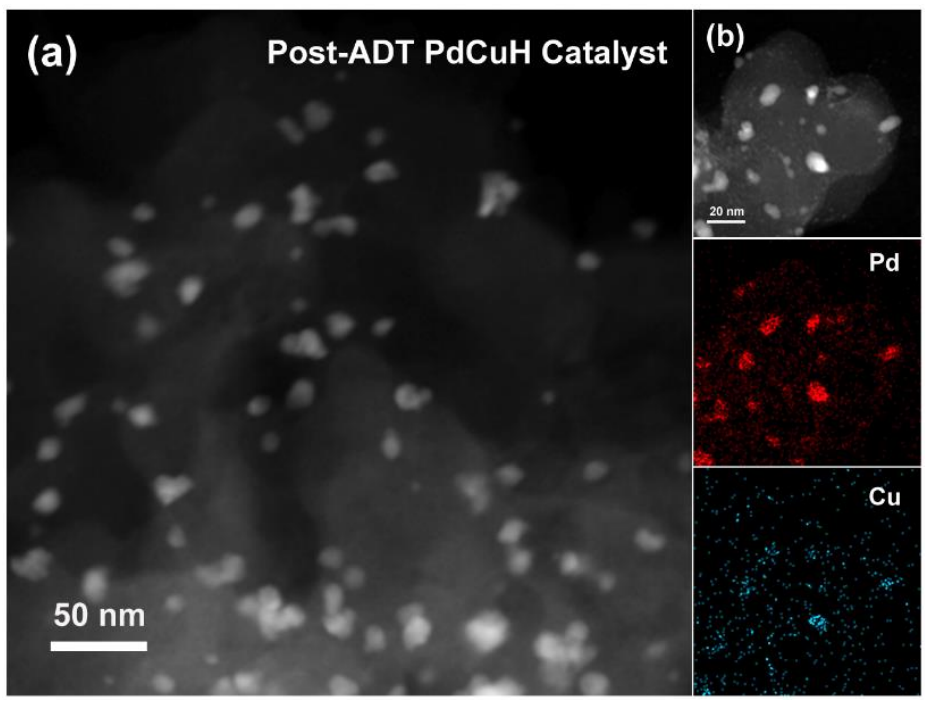

Figure S8. STEM characterization of post-ADT $\mathrm{PdCu}_{0.2} \mathrm{H}_{0.43}$ catalyst. (a) Low magnification HAADF-STEM image and (b) HAADF STEM images and corresponding EDS elemental maps. 


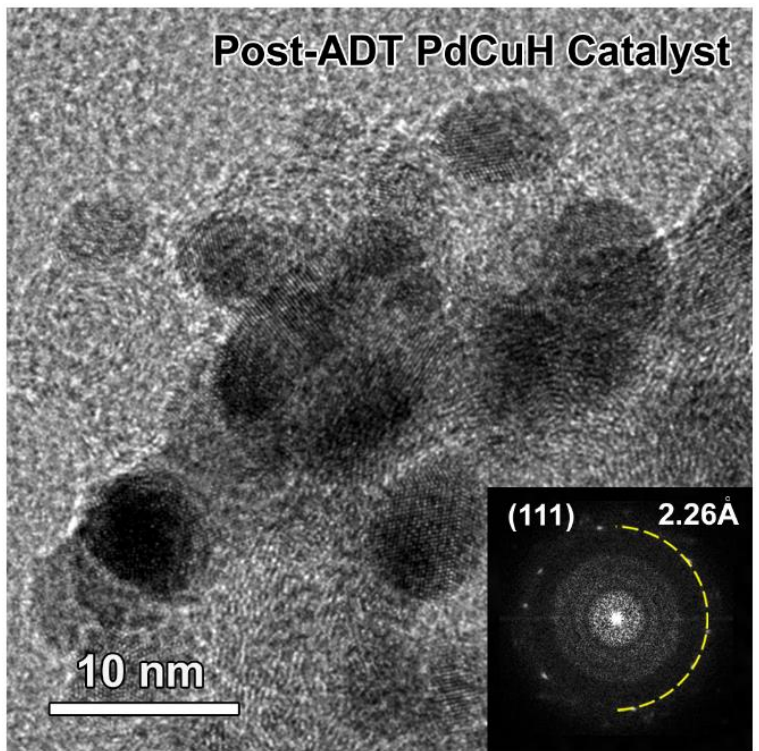

Figure S9. HRTEM characterization of post-ADT $\mathrm{PdCu} 0.2 \mathrm{H}_{0.43}$ catalyst.

\section{References}

1. Wang, G.; Liu, J.; Sui, Y.; Wang, M.; Qiao, L.; Du, F.; Zou, B. Palladium structure engineering induced by electrochemical $\mathrm{H}$ intercalation boosts hydrogen evolution catalysis. J. Mater. Chem. A 2019, 7, 14876.

2. Wang, R.; Jiang, L. Y.; Feng, J. J.; Liu, W. D.; Yuan, J.; Wang, A. J. One-pot solvothermal synthesis of $\mathrm{PdCu}$ nanocrystals with enhanced electrocatalytic activity toward glycerol oxidation and hydrogen evolution. Int. J. Hydrog. Energy. 2017, 42, 6695.

3. Bhowmik, T.; Kundu, M. K.; Barman, S. Palladium Nanoparticle-Graphitic Carbon Nitride Porous Synergistic Catalyst for Hydrogen Evolution/Oxidation Reactions over a Broad Range of $\mathrm{pH}$ and Correlation of Its Catalytic Activity with Measured Hydrogen Binding Energy. ACS Catal. 2016, 6, 1929.

4. Kresse, G.; Furthmüller, J. Efficiency of ab-initio total energy calculations for metals and semiconductors using a plane-wave basis set. Comput. Mater. Sci. 1996, 6, 15. 
5. Kresse, G.; Hafner, J. Theory of the crystal structures of selenium and tellurium: The effect of generalized-gradient corrections to the local-density approximation. Phys. Rev. B 1994, 49, 14251.

6. Perdew, J. P.; Burke, K.; Ernzerhof, M.; Generalized Gradient Approximation Made Simple. Phys. Rev. Lett. 1996, 77, 3865.

7. Hestenes, M. R.; Stiefel, E. Methods of conjugate gradients for solving linear systems. Journal of Research of the National Bureau of Standards 1952, 49, 409.

8. Cao, X. M.; Burch, R.; Hardacre, C.; Hu, P. An understanding of chemoselective hydrogenation on crotonaldehyde over $\mathrm{Pt}(111)$ in the free energy landscape: The microkinetics study based on first-principles calculations. Catal. Today 2011, 165, 71.

9. Wang, Z.; Liu, X.; Rooney, D.W.; Hu, P. Elucidating the mechanism and active site of the cyclohexanol dehydrogenation on copper-based catalysts: A density functional theory study. Surf. Sci. 2015, 640, 181.

10. Chao, T.; Luo, X.; Chen, W.; Jiang, B.; Ge, J.; Lin, Y.; Wu, G.; Wang, X.; Hu, Y.; Zhuang, Z.; Wu, Y.; Hong, X.; Li, Y. Atomically dispersed copper-platinum dual sites alloyed with palladium nanorings catalyze the hydrogen evolution reaction. Angew. Chem. Int. Ed. 2017, 56, 16047.

11. Zhang, X.; Wu D.; Cheng, D. Component-dependent electrocatalytic activity of PdCu bimetallic nanoparticles for hydrogen evolution reaction. Electrochim. Acta 2017, $246,572$.

12. Jana, R.; Bhim, A.; Bothra, P.; Pati, S. K.; Peter, S. C. Electrochemical Dealloying of $\mathrm{PdCu}_{3}$ Nanoparticles to Achieve Pt-like Activity for the Hydrogen Evolution Reaction. ChemSusChem 2016, 9, 2922.

13. Li, J.; Li, F.; Guo, S. X.; Zhang, J.; Ma, J.PdCu@Pd nanocube with Pt-like activity for hydrogen evolution reaction. ACS Appl. Mater. Interfaces 2017, 9, 8151.

14. Li, M.; Zhao, Z.; Xia, Z.; Luo, M.; Zhang, Q.; Qin, Y.; Tao, L.; Yin, K.; Chao Y.; Gu, L.; Yang, W.; Yu, Y.; Lu, G.; Guo, S. Exclusive strain effect boosts overall water splitting in PdCu/Ir core/shell nanocrystals. Angew. Chem. Int. Ed. 2021, 60, 8243. 